\title{
PENURUNAN KADAR KROM PADA AIR LIMBAH ELEKTROPLATING DENGAN MENGGUNAKAN BENTONIT AKTIF SEBAGAI ADSORBEN
}

\section{THE REDUCTION OF CHROME CONTENT IN WASTE WATER OF ELECTROPLATING USING ACTIVE BENTONITE AS ADSORBENT}

\author{
Mustafa, Muh. Irwan \\ Politeknik Negeri Samarinda Jurusan Teknik Kimia \\ Jl. Ciptomangunkusumo Kampus Gunung Lipan \\ E-mail : mu574f4@yahoo.com
}

Naskah diterima 18 Mei 2011, disetujui 7 Nopember 2011

\begin{abstract}
ABSTRAK
Limbah krom selain berasal dari industri elektroplating juga terdapat pada industri tekstil, penyamakan kulit dan buangan laboratorium. Jika dilihat dari keberadaan dan bahayanya, krom merupakan limbah yang harus ditangani lebih lanjut agar tidak memberikan dampak negatif pada mahluk hidup dan lingkungan. Untuk menghindari pencemaran terhadap lingkungan maka sebelum dibuang ke lingkungan perlu adanya pengolahan terlebih dahulu yaitu dengan menurunkan kadarnya. Salah satu cara mengurangi kadar logam berat adalah dengan metode adsorpsi dengan menggunakan adsorben bentonit aktif. Penelitian ini dimaksudkan untuk mengetahui kemampuan bentonit aktif dalam menurunkan kadar krom dalam limbah. Prosedur dalam penelitian ini meliputi preparasi bentonit, aktivasi bentonit, analisa kadar krom bahan baku (air limbah elektroplating). Adsorpsi pada perlakuan yang terbaik yaitu pada massa 25 gram dengan pengadukan $597 \mathrm{rpm}$ dan waktu kontak 4 jam. Adsorpsi pada massa 25 gram mampu menurunkan kadar krom dari kadar awal air limbah krom 394,59 mg/L menjadi 194,34 mg/L dengan penurunan kadar $\mathrm{Cr}$ sebesar $49,48 \%$
\end{abstract}

Kata Kunci : adsorpsi, air limbah electroplating, bentonit aktif , krom.

\begin{abstract}
Chrome by product comes not only from elektroplating industry but also textile industry, leather tanning and laboratory waste. Looking at its existence and hazard, chrome by product has to further handled in order not to give negative effects to living creatures and environment. To avoid polluting the environment, the waste has to be processed first by lowering its content. One of the methods to reduce the content of the heavy metal is adsorption by using active bentonite as adsorbent. The purpose of this research is to find out the ability of active bentonite in reducting the content of chrome by product in waste. The procedure in this research consists of bentonite preparation, bentonite activation, content of chrome analysis in the raw material (waste water electroplating). The optimum treatment for the adsorption was at the mass of 25 gram stirred at $597 \mathrm{rpm}$ with the contact time of 4 hours. Adsorption at the mass 25 grams could reduce chrome content from the initial chrome content waste water $394.59 \mathrm{mg} / \mathrm{L}$ to $194.34 \mathrm{mg} / \mathrm{L}$ with the reduction of chrome of $49.48 \%$
\end{abstract}

Keywords : adsorption, active bentonite, electroplating waste water, chrome. 


\section{PENDAHULUAN}

$\mathrm{S}$ emakin pesatnya aktifitas industri belakangan ini, selain memenuhi kebutuhan dan kesejahteraan manusia juga menghasilkan dampak negatif, baik untuk mahluk hidup maupun bagi lingkungan, dari setiap kegiatan industri pasti memiliki limbah dari hasil proses industrianya. Salah satu jenis industri yang memiliki dampak negatif bagi lingkungan dan mahluk hidup adalah industri elektroplating. Industri ini menghasilkan berbagai macam jenis limbah, antara lain adalah limbah logam berat seperti $\mathrm{Cr}$, Ni dan lain sebagainya. $\mathrm{Cr}$ (krom) adalah jenis logam berat yang sangat berbahaya dan tergolong dalam logam berat sangat beracun sehingga dapat menyebabkan berbagai macam penyakit seperti iritasi pada kulit, kerusakan pada mukosa, gangguan pada saluran pencernaan, kanker paru-paru dan lain sebagainya. Krom terdapat di alam dalam dua bentuk oksida yaitu $\mathrm{Cr}(\mathrm{VI})$ atau chromium hexavalent (berwarna kuning atau jingga, dikenal dengan sebutan krom) dan $\mathrm{Cr}$ (III) atau chromium trivalent (berwarna hijau dan dikenal dengan sebutan krom total)( Firnindyta, F., dkk., 2008). $\mathrm{Cr}(\mathrm{VI})$ mudah larut dalam air dan membentuk divalent oxyanion yaitu kromat $\left(\mathrm{CrO}_{4}{ }^{2-}\right)$ dan dikromat $\left(\mathrm{CrO}_{7}{ }^{2}\right)$. Tingkat toksisitas $\mathrm{Cr}(\mathrm{VI})$ sangat tinggi sehingga bersifat racun terhadap semua organisme. Standar kadar $\mathrm{Cr}$ pada air minum maksimal 0,05 ppm (SNI 013553-2006). Krom adalah logam berbentuk kristal dan berwarna abu-abu, mengkilap, keras dan tahan karat yang dilambangkan dengan " $\mathrm{Cr}$ ", mempunyai nomor atom 24 dan berat atom 51,996 gram/gmol. Semua senyawa krom bersifat racun berbahaya (Meriatna, 2008). Krom(VI) dikenal sebagai zat karsinogen yang dapat merusak fungsi kerja DNA dalam sel, sehingga dapat mengakibatkan terjadinya mutasi pada mahluk hidup. Firnindyta, F., dkk (2008) menyatakan bahwa krom(VI) dapat diserap lewat mulut, kontak dengan kulit dan pernapasan. Krom dapat menyebabkan iritasi pada kulit, kerusakan pada membran mukosa, ginjal, saluran pencernaan dan hati. Kontaminasi logam krom dapat terjadi melalui makanan dan minuman yang tertumpuk di ginjal akan mengakibatkan keracunan akut yang akan ditandai dengan kecenderungan terjadinya pembengkakan pada hati dan dalam waktu yang cukup panjang akan mengendap dan menimbulkan kanker paru-paru (Khairani, N., dkk, 2007)

Limbah krom selain berasal dari industri elektroplating juga terdapat pada industri tekstil, penyamakan kulit dan buangan laboratorium. Jika dilihat dari keberadaan dan bahayanya, krom merupakan limbah yang harus ditangani lebih lanjut agar tidak memberikan dampak negatif pada mahluk hidup dan lingkungan pada saat dibuang ke lingkungan. Limbah industri elektroplating berasal dari bahan-bahan kimia yang digunakan dan hasil dari proses pelapisan. Bahan-bahan kimia yang digunakan adalah bahan beracun sehingga limbah yang dihasilkan berbahaya bagi kesehatan manusia, baik yang terlibat langsung dengan kegiatan industri maupun yang disekitar perusahaan.

Elektroplating (pelapisan logam) merupakan pengendapan satu lapisan logam tipis pada suatu permukaan logam atau plastik yang dilakukan dengan tenaga listrik, tetapi bisa juga dilakukan dengan menggunakan reaksi kimia. Limbah industri pelapisan bermacam-macam, bersifat asam atau basa yang mengandung sianida beracun dan logam. Sumber limbah berupa larutan di dalam bejana itu sendiri atau air bilasan. Sumber utama air limbah adalah larutan pembilas yang agak encer dan sering mengandung 5 $\mathrm{mg} / \mathrm{L}$ - $50 \mathrm{mg} / \mathrm{L}$ ion logam beracun. Larutan dalam bejana yang berkonsentrasi tinggi jarang dibuang, akan tetapi jika dibuang dampak racunnya terhadap air penampung 
limbah mungkin besar. Pelapisan, perendaman dan pencelupan dalam sianida menghasilkan larutan yang mengandung sianida dan logam yang dilapisi.

Untuk menghindari pencemaran terhadap lingkungan maka sebelum dibuang ke lingkungan perlu adanya pengolahan terlebih dahulu yaitu dengan menurunkan kadarnya. Salah satu cara mengurangi kadar logam berat adalah dengan metode adsorpsi dengan menggunakan adsorben bentonit aktif.

Bentonit merupakan salah satu jenis lempung yang mana komposisi terbesarnya adalah monmorilonit yaitu sekitar $80 \%$ hingga 90\% terdiri dari kristal alumino-silikat terhidrasi yang mengandung kation alkali atau alkali tanah dalam kerangka tiga dimensi. Ionion logam tersebut dapat diganti oleh kation lain tanpa merusak struktur bentonit dan dapat menyerap air secara reversible. Bentonit tidak dapat diidentifikasi hanya berdasarkan analisa komposisi kimianya saja, melainkan harus dianalisa strukturnya. Struktur kristal bentonit, semua atom Si dalam bentuk tetrahedral, sedangkan atom Al dalam bentuk Oktahedral.

Lempung bentonit sangat menarik untuk diteliti karena lempung ini mempunyai struktur berlapis dengan kemampuan mengembang (swelling) dan memiliki kation-kation yang dapat ditukarkan. Daya adsorpsi bentonit dapat ditingkatkan melalui proses aktivasi menggunakan asam $(\mathrm{HCl}$, $\mathrm{H}_{2} \mathrm{SO}_{4}$ dan $\mathrm{HNO}_{3}$ ) sehingga dihasilkan lempung dengan kemampuan adsorpsi yang lebih tinggi (Kumar and Jasra, 1995). Aktivasi lempung menggunakan asam akan menghasilkan lempung dengan situs aktif lebih besar dan keasamaan. Permukaan yang lebih besar, sehingga akan dihasilkan lempung dengan kemampuan adsorpsi yang lebih tinggi dibandingkan sebelum diaktivasi.

Berdasarkan proses terbentuknya di alam, bentonit dibagi menjadi dua golongan, yaitu: Na-Bentonit(Swelling Bentonite) dan Ca-Bentonit (Non
Swelling Bentonite). Na-bentonit dimanfaatkan sebagai bahan perekat, pengisi (filter), sesuai sifatnya mampu membentuk suspensi kental setelah bercampur dengan air, lumpur pemboran minyak bumi/gas/panas bumi, bleaching powder minyak sawit, indutri kimia, farmasi, pencampur semen, insektisida, sabun. Sedangkan Cabentonit banyak dipakai sebagai bahan penyerap, bahan pembuat $\mathrm{Na}$-bentonit dengan proses pengaktifan dengan asam.

Untuk meningkatkan kemampuan daya serap dan daya tukar ionnya, bentonit harus diaktivasi terlebih dahulu dengan pemanasan dan modifikasi dengan asam agar porositas, luas permukaan dan keasamannya meningkat (Purnomo, A., 2007). Pengolahan lanjut ini bertujuan untuk meningkatkan mutu bentonit antara lain dengan poses pengaktifan. Potensi cadangan lempung bentonit di Indonesia sangatlah besar dan tersebar hampir di seluruh daerah terutama di pulau Jawa dan Sumatera. Namun hingga saat ini pemanfaatan bentonit belum optimal.

\section{BAHAN DAN METODE}

\section{Bahan dan Peralatan}

Bahan yang digunakan pada penelitian ini adalah bentonit alam, aquadest, $\quad \mathrm{CuCl}_{2} \cdot 2 \mathrm{H}_{2} \mathrm{O}$, air limbah elektroplating, $\mathrm{AgNO}_{3}$, buffer asetat, $\mathrm{HCl}$ pekat, $\mathrm{KI}, \mathrm{K}_{2} \mathrm{Cr}_{2} \mathrm{O}_{7}$ dan $\mathrm{H}_{2} \mathrm{C}_{2} \mathrm{O}_{4}$. Sedangkan Peralatan utama yang digunakan terdiri dari alat untuk pembuatan adsorben dan Kalsinasi. Peralatan pembuatan adsorben terdiri dari labu leher tiga, pendingin, pemanas air dan pengaduk. Alat untuk Kalsinasi bentonik adalah furnace dan desikator sedangkan untuk analisa kadar krom digunakan alat SSA (spektrofotometer Serapan Atom). 


\section{Metode}

Preparasi material pori bentonit

1. Menimbang 200 gram bentonit alam dan mengayaknya 100 mesh.

2. Menimbang 130 gram bentonit powder yang telah di ayak dan memasukkannya ke dalam gelas kimia 2 liter.

3. Menambahkan aguadest $1950 \mathrm{~mL}$ kedalam gelas kimia 2 liter dan diaduk dengan stirrer pada kecepatan pengadukan 419,5 rpm selama 5 jam kemudian didiamkan hingga 24 jam.

4. Menyaring suspensi bentonit dengan menggunakan kertas saring no. 40 .

5. Mengeringkan endapan bentonit yang telah disaring dalam oven pada suhu $100{ }^{\circ} \mathrm{C}$ hingga bentonit kering kemudian ditimbang.

6. Menggerus bentonit kering dan mengayaknya pada ukuran 100 mesh (bentonit powder).

\section{Aktivasi}

1. Menimbang 90 gram bentonit powder yang telah melewati proses preparasi dan memasukkannya dalam labu leher dua 1 liter.

2. Menambahkan $900 \mathrm{~mL}$ $\mathrm{CuCl}_{2} \cdot 2 \mathrm{H}_{2} \mathrm{O} \quad 0,3 \mathrm{M}$ kedalam labu leher dua 1 liter kemudian menambahkan buffer asetat hingga $\mathrm{pH}<3$.

3. Merefluks suspensi bentonit selama 5 jam pada suhu $70{ }^{\circ} \mathrm{C}$ disertai dengan pengadukan dengan menggunakan stirrer pada kecepatan pengadukan 1192 rpm, kemudian suspensi didinginkan hingga suhu ruangan.

4. Menyaring suspensi yang telah dingin dengan menggunakan kertas saring no. 40 .

5. Setelah penyaringan selesai dilanjutkan dengan uji $\mathrm{Cl}^{-}$ menggunakan aguadest dan $\mathrm{AgNO}_{3} 1 \mathrm{M}$.
6. Bentonit bebas $\mathrm{Cl}^{-}$dikeringkan pada suhu $110^{\circ} \mathrm{C}$ selama 5 jam, kemudian didinginkan selama 2 jam.

7. Bentonit terinterkalasi kemudian dikalsinasi dengan menggunakan furnace pada suhu $300^{\circ} \mathrm{C}$ selama 5 jam hingga diperoleh $\mathrm{Cu}-\mathrm{Bp}(\mathrm{Cu}-$ Bentonit powder/Bentonit aktif) kemudian ditimbang.

\section{Proses adsorpsi variasi massa bentonit}

1. Menyiapkan sampel limbah elektroplating sebanyak $100 \mathrm{~mL}$ ke dalam gelas kimia $200 \mathrm{~mL}$.

2. Menimbang 5 gram bentonit aktif dan memasukkannya ke dalam sampel limbah.

3. Melakukan proses adsorpsi dengan mengontakkan bentonit dan limbah selama 1 jam disertai dengan pengadukan pada kecepatan $188 \mathrm{rpm}$.

4. Setelah 1 jam pengadukan dihentikan dan menyaring sampel limbah dengan menggunakan pompa vakum dan kertas saring no. 40.

5. Mereduksi sampel limbah untuk merubah $\mathrm{Cr}^{6+}$ menjadi $\mathrm{Cr}^{3+}$ agar dapat terbaca pada alat spektrofotometer serapa atom dengan menggunakan reduktor asam oksalat $\left(\mathrm{H}_{2} \mathrm{C}_{2} \mathrm{O}_{4}\right)$.

6. Menganalisa kadar krom sampel dengan menggunakan alat spektrofotometer serapan atom dengan konsentrasi larutan standar $(10,20,30,40$ dan 50) ppm dan mencatat konsentrasinya.

7. Mengulangi prosedur nomor 1 hingga 6 dengan memvariasikan massa bentonit yaitu 10 gram, 15 gram, 20 gram dan 25 gram.

Proses adsorpsi variasi kecepatan pengadukan

1. Menyiapkan sampel limbah elektroplating sebanyak $100 \mathrm{~mL}$ ke dalam gelas kimia $200 \mathrm{~mL}$. 
2. Menimbang 10 gram bentonit aktif dan memasukkannya ke dalam sampel limbah.

3. Melakukan proses adsorpsi dengan mengontakkan bentonit dan limbah selama 1 jam disertai dengan pengadukan pada kecepatan $60 \mathrm{rpm}$.

4. Setelah 1 jam pengadukan dihentikan dan menyaring sampel limbah dengan menggunakan pompa vakum dan kertas saring no. 40.

5. Mereduksi sampel limbah untuk merubah $\mathrm{Cr}^{6+}$ menjadi $\mathrm{Cr}^{3+}$ agar dapat terbaca pada alat spektrofotometer serapan atom dengan menggunakan reduktor asam oksalat $\left(\mathrm{H}_{2} \mathrm{C}_{2} \mathrm{O}_{4}\right)$.

6. Menganalisa kadar krom sampel dengan menggunakan alat spektrofotometer serapan atom dengan konsentrasi larutan standar $(10,20,30,40$ dan 50) ppm dan mencatat konsentrasinya.

7. Mengulangi prosedur nomor 1 hingga 6 dengan memvariasikan kecepatan pengadukan yaitu 117 rpm, 297 rpm, 597 rpm dan 1092 rpm.

Proses adsorpsi variasi waktu kontak

1. Menyiapkan sampel limbah elektroplating sebanyak $100 \mathrm{~mL}$ ke dalam gelas kimia $200 \mathrm{~mL}$.

2. Menimbang 10 gram bentonit aktif dan memasukkannya ke dalam sampel limbah.

3. Melakukan proses adsorpsi dengan mengontakkan bentonit dan limbah selama 1 jam disertai dengan pengadukan pada kecepatan $188 \mathrm{rpm}$.

4. Setelah 1 jam pengadukan dihentikan dan menyaring sampel limbah dengan menggunakan pompa vakum dan kertas saring no. 40.

5. Mereduksi sampel limbah untuk merubah $\mathrm{Cr}^{6+}$ menjadi $\mathrm{Cr}^{3+}$ agar dapat terbaca pada alat spektrofotometer serapan atom dengan menggunakan reduktor asam oksalat $\left(\mathrm{H}_{2} \mathrm{C}_{2} \mathrm{O}_{4}\right)$.

6. Menganalisa kadar krom sampel dengan menggunakan alat spektrofotometer serapan atom dengan konsentrasi larutan standar $(10,20,30,40$ dan 50) $\mathrm{mg} / \mathrm{L}$ dan mencatat konsentrasinya.

7. Mengulangi prosedur nomor 1 hingga 6 dengan memvariasikan waktu kontak yaitu 2 jam, 3 jam, 4 jam dan 5 jam.

\section{Proses adsorpsi pada kondisi terbaik}

1. Menyiapkan sampel limbah elektroplating sebanyak $100 \mathrm{~mL}$ ke dalam gelas kimia $200 \mathrm{~mL}$.

2. Menimbang 25 gram bentonit aktif dan memasukkannya ke dalam sampel limbah.

3. Melakukan proses adsorpsi dengan mengontakkan bentonit dan limbah selama 4 jam disertai dengan pengadukan pada kecepatan $597 \mathrm{rpm}$.

4. Setelah 4 jam pengadukan dihentikan dan menyaring sampel limbah dengan menggunakan pompa vakum dan kertas saring no. 40.

5. Mereduksi sampel limbah untuk merubah $\mathrm{Cr}^{6+}$ menjadi $\mathrm{Cr}^{3+}$ agar dapat terbaca pada alat spektrofotometer serapan atom dengan menggunakan reduktor asam oksalat $\left(\mathrm{H}_{2} \mathrm{C}_{2} \mathrm{O}_{4}\right)$.

\section{Analisa Kadar Krom dengan Alat Spektofotometri Serapan Atom (Menggunakan Metode SNI 6989.17:2009)}

\section{Persiapan Pengujian}

- $\quad$ Menimbang 1 gram $\mathrm{H}_{2} \mathrm{C}_{2} \mathrm{O}_{4} \cdot 2 \mathrm{H}_{2} \mathrm{O}$ ke dalam gelas kimia $250 \mathrm{~mL}$.

- Menambahkan aguadest hingga volume $100 \mathrm{~mL}$ dan dipanaskan disertai dengan pengadukan.

Menambahkan $\mathrm{HCl}$ pekat sampai $\mathrm{pH}=2$ dan mendinginkannya.

Memindahkan larutan ke dalam labu ukur $250 \mathrm{~mL}$ dan 
mengencerkannya hingga tanda batas lalu menghomogenkannya.

Pembuatan larutan induk krom 100 $\mathrm{mg} / \mathrm{L}$

- $\quad$ Menimbang 70,719 $\mathrm{mg} \mathrm{K}_{2} \mathrm{Cr}_{2} \mathrm{O}_{7}$.

- $\quad$ Menimbang 96,791 $\mathrm{mg} \mathrm{H}_{2} \mathrm{C}_{2} \mathrm{O}_{4}$

- Melarutkan kedua bahan hablur di atas dengan menggunakan aquadest secukupnya.

- Memanaskan campuran di atas hot plate sambil dilakukan pengadukan.

- Menambahkan $\mathrm{HCl}$ pekat pada campuran hingga $\mathrm{pH} 2$.

- Campuran dibiarkan hingga warna berubah menjadi hijau, kemudian larutan dibiarkan hingga dingin (suhu ruangan).

- Setelah larutan mencapai suhu ruangan, larutan dimasukan dalam labu ukur $250 \mathrm{~mL}$ dan diencerkan dengan aquadest hingga tanda batas.

- Mengocok larutan hingga homogen.

Pembuatan larutan standar krom (konsentrasi 10, 20, 30, 40 dan 50) $\mathrm{mg} / \mathrm{L}$

- Memipet $10 \mathrm{~mL}$ larutan induk dengan menggunakan pipet volume ke dalam labu ukur 100 $\mathrm{mL}$.

Menambahkan aquadest ke dalam labu ukur hingga tanda batas.

Mengocok larutan hingga larutan menjadi homogen.

Mengulangi prosedur pada nomor 1 hingga 3 untuk konsentrasi 20 $\mathrm{mg} / \mathrm{L}, 30 \mathrm{mg} / \mathrm{L}, 40 \mathrm{mg} / \mathrm{L}$ dan 50 $\mathrm{mg} / \mathrm{L}$ dengan memipet larutan induk sebanyak $20 \mathrm{~mL}, 30 \mathrm{~mL}, 40$ $\mathrm{mL}$ dan $50 \mathrm{~mL}$ secara berturutturut.

\section{Analisis Hasil}

Analisis hasil dilakukan dengan cara membandingan konsentrasi krom pada air limbah awal dan konsentrasi krom pada air limbah setelah dilakukan proses adsorpsi oleh bentonit aktif dengan menggunakan alat spektofotometri serapan atom, sehingga dapat diketahui kemampuan bentonit aktif sebagai adsorben.

Pengukuran kadar bentonit aktif dengan menggunakan persamaan:

Penurunan Kadar Krom $=\frac{C_{0-} C_{1}}{C_{0}} \times 100 \%$

Keterangan:

$\mathrm{C}_{0}=$ Konsentrasi krom sebelum proses adsorpsi (mg/L)

$\mathrm{C}_{1}=$ Konsentrasi krom setelah mengalami proses adsorpsi (mg/L)

\section{HASIL DAN PEMBAHASAN}

Lempung Bentonit yang digunakan dalam penelitian ini yaitu lempung Bentonit dan limbah cair electroplating. Bahan-bahan ini memiliki komposisi seperti yang disajikan pada Tabel di bawah ini.

\section{Analisa Bahan Baku (bentonit alam)}

Tabel 1. Komposisi Kimia Bentonit Alam

\begin{tabular}{ccc}
\hline No & Komponen & Konsentrasi (\%) \\
\hline 1 & $\mathrm{SiO}_{2}$ & 51,50 \\
2 & $\mathrm{AlO}_{2} \mathrm{O}^{3}$ & 18,13 \\
3 & $\mathrm{Fe}_{2} \mathrm{O}_{3}$ & 5,67 \\
4 & $\mathrm{TiO}_{2}$ & 0,56 \\
5 & $\mathrm{MnO}_{2}$ & 0,02 \\
6 & $\mathrm{CaO}^{2}$ & 2,78 \\
7 & $\mathrm{MgO}$ & 1,25 \\
8 & $\mathrm{KO}$ & 0,32 \\
9 & $\mathrm{NaO}_{2}$ & 3,74 \\
10 & $\mathrm{LOI}$ & 16,00 \\
\hline
\end{tabular}

Sumber : Purnomo, 2007

Analisa Bahan Baku (Air Limbah Elektroplating)

Sampel yang digunakan dalam penelitian ini adalah air limbah elektroplating dengan konsentrasi kadar krom 394,59 mg/L 


\section{Variasi Massa Bentonit}

Tabel 3. Hasil adsorpsi variasi massa bentonit

\begin{tabular}{cccc}
\hline No & $\begin{array}{c}\text { Massa } \\
\text { bento } \\
\text { nit } \\
\text { (gram) }\end{array}$ & $\begin{array}{c}\text { Konsentra } \\
\text { si Krom } \\
\text { (mg/L) }\end{array}$ & $\begin{array}{c}\text { Penurun } \\
\text { an Kadar } \\
\text { Cr }(\%)\end{array}$ \\
\hline 1 & 5 & 393,27 & 0,33 \\
2 & 10 & 315,43 & 20,06 \\
3 & 15 & 262,53 & 33,47 \\
4 & 20 & 225,13 & 42,95 \\
5 & 25 & 192,69 & 51,17 \\
\hline
\end{tabular}

\section{Variasi Kecepatan Pengadukan}

Tabel 4. Hasil Adsorpsi Variasi Kecepatan Pengadukan

\begin{tabular}{|c|c|c|c|}
\hline No & $\begin{array}{c}\text { Kecepat } \\
\text { an } \\
\text { pengadu } \\
\text { kan } \\
(\mathrm{rpm})\end{array}$ & $\begin{array}{c}\text { Konsen } \\
\text { trasi } \\
\text { Krom } \\
(\mathrm{mg} / \mathrm{L})\end{array}$ & $\begin{array}{c}\text { Penurun } \\
\text { an Kadar } \\
\text { Cr (\%) }\end{array}$ \\
\hline
\end{tabular}

\begin{tabular}{cccc}
\hline 1 & 60 & 321,41 & 18,55 \\
2 & 117 & 305,14 & 22,67 \\
3 & 297 & 300,60 & 23,82 \\
4 & 597 & 270,07 & 31,56 \\
5 & 1092 & 291,46 & 26,14 \\
\hline
\end{tabular}

Variasi Waktu Kontak

Tabel 5. Hasil Adsorpsi Variasi Waktu Kontak

\begin{tabular}{cccc} 
No & $\begin{array}{c}\text { Waktu } \\
\text { kontak } \\
\text { (jam) }\end{array}$ & $\begin{array}{c}\text { Konsent } \\
\text { rasi Krom } \\
(\mathrm{mg} / \mathrm{L})\end{array}$ & $\begin{array}{c}\text { Penurun } \\
\text { an Kadar } \\
\mathrm{Cr}(\%)\end{array}$ \\
\hline 1 & 1 & 315,43 & 20,06 \\
2 & 2 & 291,45 & 26,14 \\
3 & 3 & 282,73 & 28,35 \\
4 & 4 & 261,38 & 33,76 \\
5 & 5 & 268,18 & 32,04 \\
\hline
\end{tabular}

\section{Kondisi Terbaik}

Tabel 6. Hasil Adsorpsi Pada Kondisi Terbaik

\begin{tabular}{ccccc}
\hline $\begin{array}{c}\text { Massa } \\
\text { Bentonit } \\
(\mathrm{gram})\end{array}$ & $\begin{array}{c}\text { Kecepatan } \\
\text { pengadukan } \\
(\mathrm{rpm})\end{array}$ & $\begin{array}{c}\text { Waktu } \\
\text { Kontak } \\
(\mathrm{jam})\end{array}$ & $\begin{array}{c}\text { Konsentrasi } \\
(\mathrm{mg} / \mathrm{L})\end{array}$ & $\begin{array}{c}\text { Penurunan Kadar Cr } \\
(\%)\end{array}$ \\
\hline 25 & 597 & 4 & 199,34 & 49,48 \\
\hline
\end{tabular}

Hasil penelitian meliputi kajian tentang kemampuan bentonit aktif dengan variasi massa bentonit, kecepatan pengadukan dan waktu kontak yang digunakan untuk menurunkan kadar krom pada air limbah elektroplating. Kondisi ini untuk mengetahui perlakuan yang terbaik dari bentonit aktif sebagai adsorben. Penentuan kondisi terbaik dilakukan untuk mengetahui penyerapan krom pada limbah oleh bentonit aktif, sehingga penyerapan krom oleh bentonit aktif dapat dilakukan lebih baik.

\section{Pengaruh Massa Bentonit}

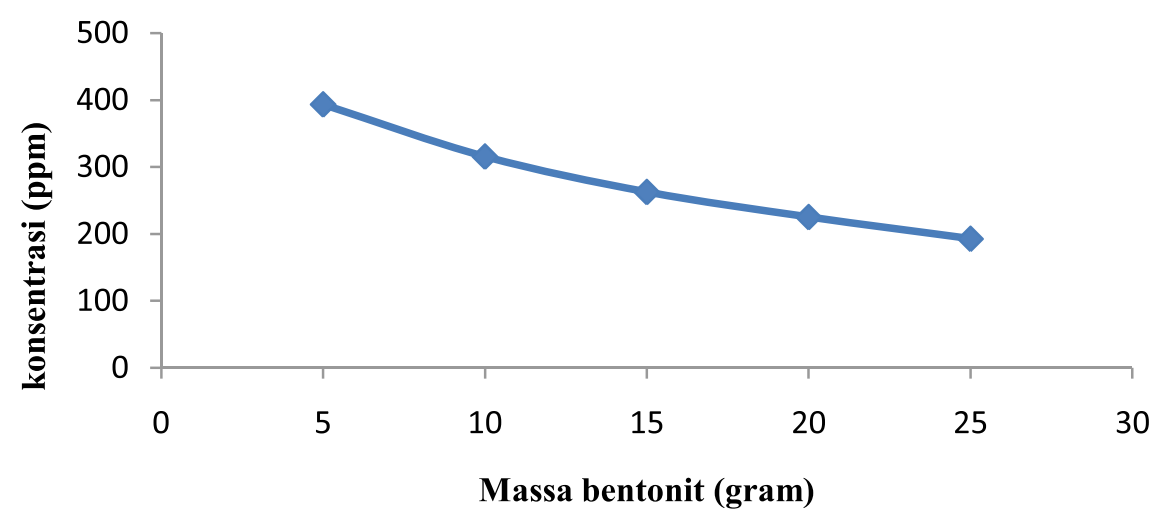

Gambar 1. Hubungan antara massa bentonit aktif terhadap konsentrasi krom 
Berdasarkan gambar 1 adalah massa terbaik terjadi pada perlakuan massa bentonit aktif 25 gram. Gambar ini menunjukkan bahwa penambahan massa sangat mempengaruhi penurunan kadar krom, dimana semakin besar massa bentonit maka sifat adsorpsinya semakin baik atau penurunan kadar krom semakin meningkat sebanyak $51,17 \%$

Bentonit aktif merupakan adsorben yang memiliki pori yang dapat menyerap krom pada air limbah, semakin besar massa bentonit aktif yang dikontakkan dengan limbah yang mengandung krom maka akan semakin banyak pori bentonit yang dapat menyerap krom dari air limbah sehingga kadar krom yang tertinggal dalam air limbah akan semakin sedikit.

Hasil penelitian menunjukan kadar krom semakin menurun sebelum mencapai kecepatan pengadukan terbaik (597 rpm), disebabkan dengan semakin besarnya kecepatan pengadukan maka kontak antara adsorben (bentonit aktif) dan adsorbat (krom dalam air limbah) akan semakin Merata. Namun setelah mencapai kecepatan pengadukan terbaik kadar krom meningkat kembali, kemungkinan dikarenakan Kecepatan pengadukan yang terlalu besar mengakibatkan krom yang telah terserap dalam pori bentonit aktif terdorong keluar kembali Sebagaimana tersaji pada Ganbar 2. Asumsi lain menyebutkan bahwa proses pengadukan akan mengakibatkan terjadinya tumbukan antara partikel adsorben secara tepat dan kontinyu, sehingga ada kemungkinan adsorbat akan dilepaskan kembali oleh adsorben (Amin Purnomo, 2007).

\section{Pengaruh Kecepatan Pengadukan}

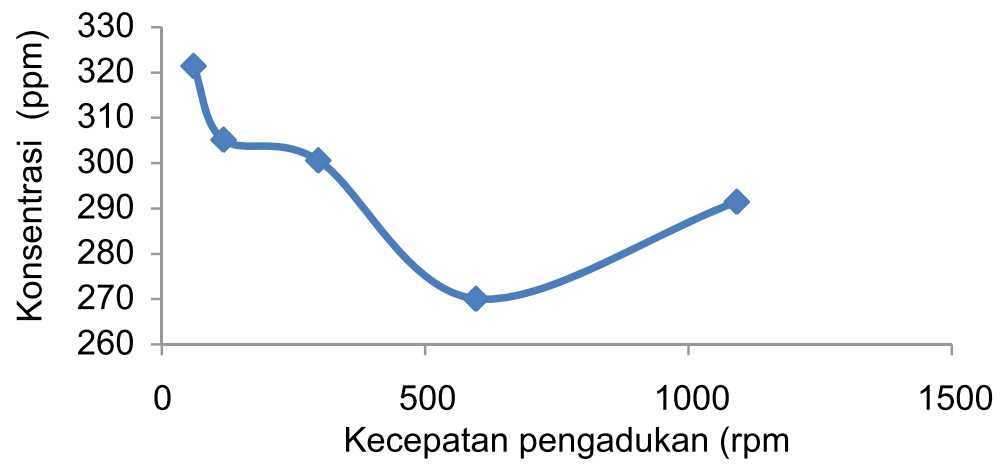

Gambar 2. Hubungan antara kecepatan pengadukan terhadap konsentrasi krom

\section{Pengaruh Waktu Kontak}

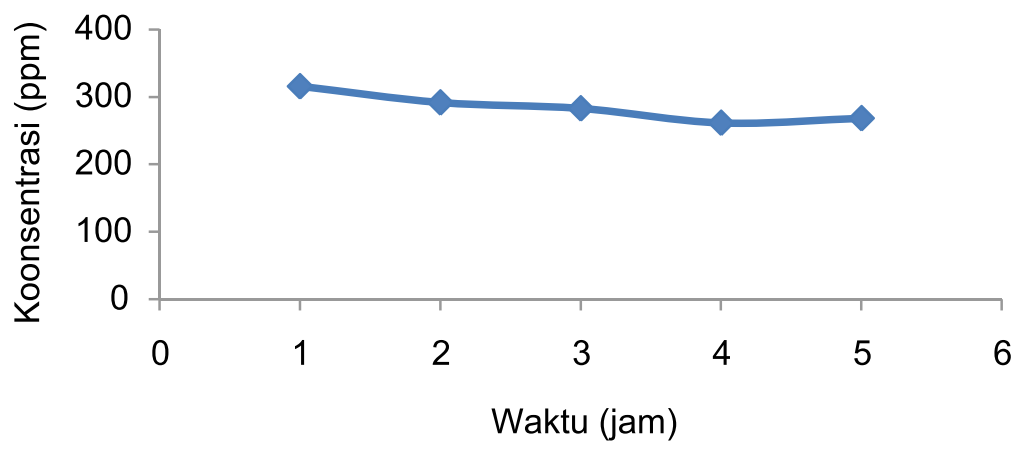

Gambar 3. Hubungan antara waktu kontak terhadap konsentrasi krom 
Dari gambar 3 tersebut di atas hasil adsorpsi menunjukan waktu kontak terbaik dicapai pada waktu 4 jam. Sebelum mencapai waktu kontak terbaik hubungan waktu dengan kadar krom berbanding terbalik, dimana semakin lama waktu kontak mengakibatkan kadar krom dalam limbah semakin kecil. Hal ini dikarenakan semakin lama waktu kontak antara limbah krom dan adsorben bentonit aktif, maka semakin banyak krom yang teradsorpsi oleh bentonit aktif. Bentonit aktif merupakan adsorben yang memiliki pori yang dapat digunakan untuk menyerap krom dalam limbah (adsorbat), sehingga semakin lama waktu kontak antara adsorben dan adsorbat maka akan semakin banyak adsorbat yang terserap ke dalam pori adsorben. Selain itu juga semakin lama waktu kontak maka tumbukan antar partikel adsoben dan adsorbat akan semakin lama, dan tumbukan ini akan mengakibatkan semakin banyaknya adsorbat yang masuk dalam adsorben yang memiliki pori yang lebih besar dibanding dengan ukuran adsorbat. Namun setelah melewati waktu kontak terbaik yaitu pada waktu 5 jam kadar krom meningkat kembali, hal ini menunjukkan telah tercapainya kesetimbangan adsorpsi. Penurunan jumlah kadar krom yang teradsorpsi ini di asumsikan terjadi akibat adanya interaksi adsorben dengan adsorbat yang kelewat jenuh, dimana spesies adsorbat yang teradsorpsi oleh adsorben terlalu lama (melebihi waktu terbaik).

\section{Proses Adsorpsi Pada Kondisi Terbaik}

Pada tabel 6 menunjukkan bahwa bentonit aktif mampu menyerap krom hingga 49,48\% (195,25 mg/L) pada perlakuan massa bentonit 25 gram, kecepatan pengadukan $597 \mathrm{rpm}$ dan waktu kontak 4 jam. Hasil tersebut menunjukkan bahwa bentonit aktif dengan aktivator $\mathrm{CuCl}_{2}$ merupakan adsorben yang baik dengan perbandingan massa bentonit aktif dan air limbah sebesar 1:2 dan waktu kontak 4 jam, dapat menurunkan kadar krom pada air limbah sebanyak 380,73 mg/L

Dibandingkan dengan adsorbenadsorben yang digunakan untuk penurunan kadar krom dalam air limbah pada penelitian sebelumnya yaitu kayu apu, zeolit alam, karbon aktif dan kulit batang jambu biji, ini menunjukkan bahwa bentonit aktif dapat bersaing. Dimana kayu apu dapat menurunkan kadar krom sebesar 73,6089 mg/L dengan waktu kontak 96 jam, zeolit alam sebesar 9,05 mg/L dengan waktu kontak 0,83 jam, karbon aktif 9,9 mg/L dengan waktu kontak 0,25 jam dan kulit batang jambu biji sebesar 9,9 mg/L dengan waktu kontak 1,25 jam.( Kartohardjono, S., 2008)

\section{KESIMPULAN}

Kadar krom dalam air limbah elektroplating dapat diturunkan dengan menggunakan bentonit aktif sebagai adsorben, dengan massa bentonit aktif 25 gram, kecepatan pengadukan 597 rpm dan waktu kontak 4 jam dengan volume air limbah $100 \mathrm{~mL}$ dapat menurunkan kadar krom dari kadar awal air limbah krom 394,59 mg/L menjadi $199,34 \mathrm{mg} / \mathrm{L}$ dengan penurunan kadar krom sebesar $49,48 \%$.

\section{DAFTAR PUSTAKA}

Badan Standardisasi Nasional Indonesia., 2006, SNI-01-35532006, Persyaratan Mutu Air Minum Dalam Kemasan, Jakarta

Badan Standardisasi Nasional., 2009, SNI 6989.17:2009, Air dan Air Limbah - Bagian 17 : Cara Uji Krom Total (Cr-T) Secara Spektrofotometri Serapan Atom (SSA) - nyala , Jakarta

Firnindyta, F., Suhartana dan Didik Setiyo Widodo, 2008, Pengaruh pH Pada Proses Reduksi krom(VI) Menjadi krom(III) Dengan Menggunakan Besi(II) Sulfat, 
Jurusan Kimia, Universitas Diponegoro, Semarang.

Kartohardjono, S., 2008, Pemanfaatan Jambu Biji (Psidium Guajava) Untuk Adsorpsi Cr(VI) dari Larutan, Teknik Kimia, Universitas Indonesia, Depok

Khairani, N., M. Azam, K. Sofian F. dan Soeleman, 2007, Penentuan Kandungan Unsur Krom Dalam Limbah Tekstil Dengan Metode Analisis Pengaktifan Neutron, Jurusan Fisika FMIPA, Universitas Diponegoro, Semarang.

Kumar, P. and Jasra, R. V., 1995, "Evolution of Porosity and
Surface Acidity in Montmorillonite Clay on Acid Activation", Ind. Eng. Chem. Res., 34,1440 1448

Meriatna, 2008, Penggunaan Membran Kitosan Untuk Menurunkan Kadar Logam Krom (Cr) dan Nikel (Ni) Dalam Limbah Cair Industri Pelapisan Logam, Laporan Tesis, Teknik Kimia, Universitas Sumatera Utara, Medan.

Purnomo, A., 2007, Sintesis, Karakterisasi Bentonit Terinterkalasi, Program Pasca Sarjana, Universitas Gajah Mada, Yogyakarta.. 